\title{
Dental caries in three-year-old preschool children in Lima, Peru assessed according to the CAST instrument
}

\author{
Eraldo Pesaressi' ${ }^{1}$ Rita S. Villena' ${ }^{1}$ Ewald M. Bronkhorst ${ }^{2}$ and Jo E. Frencken ${ }^{3}$ \\ ' Universidad San Martín de Porres, Facultad de Odontología. Departamento de Odontología Pediátrica, Lima, Perú. \\ ${ }^{2}$ Radboud University Medical Centre, College of Oral Sciences, Department of Preventive and Restorative Dentistry, \\ Nijmegen, The Netherlands. \\ ${ }^{3}$ Radboud University Medical Centre, College of Oral Sciences, Department of Oral Function and Prosthetic Dentistry, \\ Nijmegen, The Netherlands.
}

\begin{abstract}
The aim of this study was to determine the caries situation of three-year-old preschool children residing in low socioeconomic status districts in Lima, Peru. The study is a crosssectional analysis of the caries situation of suburban areas of Lima. A stratified sampling procedure by geographical distribution, considering healthcare centers with a motherand-child health clinic and surrounding preschools as factors, identified 45 randomly selected preschools, of which 17 accepted to participate. Children from 3-year-old classrooms were examined by two independent calibrated dentists using the Caries Assessment Spectrum and Treatment (CAST) instrument at their premises using artificial light, sterile examination mirrors and gauze for drying each tooth before evaluation. ANOVA and the Tamhane method were used to analyze the
\end{abstract}

data. 308 children, mean age 3.4 years (min: 3 years; max: 3 years, 7 months), were examined. The sample prevalence of enamel and dentine carious lesions (CAST code 3-7) was 91.2\% while the prevalence of dentine carious lesions (CAST code 4-7) was 58.8\%. The mean number of teeth with cavities that had reached the pulp and those that had an abscess or fistula were $2.0 \%$ and $0.5 \%$ respectively. The majority of enamel and dentine carious lesions were observed in molars. The CAST severity score was 7.0. Mean examination time was 57 seconds. The burden of dental caries of the children at this young age was high.

Received: November 2019; Accepted: June 2020.

Keywords: dental caries- cross sectional studies- epidemiologypublic health dentistry-child, preschool.

\section{Caries dental en niños prescolares de 3 años en Lima-Perú evaluados con el instrumento CAST}

\section{RESUMEN}

El objetivo del presente estudio fue determinar la prevalencia de caries dental en niños en edad preescolar de 3 años residentes en áreas suburbanas de Lima, Perú. Se trata de un análisis transversal de la situación de caries de áreas periféricas de Lima. Un procedimiento de muestreo estratificado por distribución geográfica consideraba a los centros de salud materno-infantiles y centros educativos preescolares de la jurisdicción como factores, identificando 45 centros prescolares aleatoriamente, de los cuales 17 aceptaron la invitación para participar del presente estudio. Dos odontólogas independientes, calibradas examinaron a los niños de las aulas de 3 años utilizando el instrumento Caries Assessment Spectrum and Treatment (CAST) en las instalaciones de cada jardin de infancia, utilizando luz artificial, instrumental estéril y gasas para el secado de las superficies a evaluar. Los datos fueron analizados utilizando ANOVA y el método Tamhane. Se evaluaron 308 niños, quienes tenían una edad media de 3.4 años (min: 3 años; max: 3 años, 7 meses). La prevalencia de lesiones de caries de esmalte y dentina (código CAST 3-7) fue del 91,2\%, mientras que la prevalencia de lesiones de caries en dentina (código CAST 4-7) fue de 58,8\%. El número promedio de dientes afectados por caries dental con compromiso pulpar y que tenían un absceso o fistula fue de $2.0 \%$ y $0.5 \%$ respectivamente. La mayoría de las lesiones de caries en esmalte y dentina se observaron en los molares. La valoración de severidad CAST fue 7.0. El tiempo promedio de examinación fue de 57 segundos. La carga de la enfermedad caries dental a estas edades tan tempranas ya es alta en la infancia suburbana de Lima.

Palabras clave: caries dental- estudios de corte transversalepidemiología-salud pública odontológica-niños, preescolares. 


\section{INTRODUCTION}

Despite being preventable, dental caries is the main public health problem worldwide and its consequences are often untreated ${ }^{1}$. The clinical signs manifest initially as enamel white-colored lesions, which may develop into cavitated dentine lesions. The progression of a carious lesion is an unwanted situation that could affect a child's normal development during early years of life by impeding proper nutrition, proper sleep and the development of self-esteem ${ }^{2,3}$. Untreated dentine carious lesions may even result in pain and suffering, and may lead to pulp involvement, abscesses, fistula and early extraction of these recently emerged primary teeth ${ }^{4}$. Low socio-economic status (SES) and limited education of mothers have been reported as major risk factors for the development of carious lesions in children ${ }^{5}$. High-caries-risk mothers and their children have a tendency to visit the dental practitioner only when the consequences of the disease are evident. To avoid this situation, the dental practitioner has to consider ways to interact with parents as from the time their children's teeth erupt. The obvious place where this should happen is at the motherand-child health clinics at healthcare centers. As dental personnel are not usually employed at these centers, they should actively seek involvement with center health professionals ${ }^{6}$. Nurses appear to be the most appropriate health professionals to engage with because they see parents on a regular basis as part of their children's vaccination, growth and development program. But in order for nurses to be effective in improving the oral health of infants, they need to be educated in oral health promotion and preventive measures ${ }^{7}$.

To measure the impact of nurses in a primary oral healthcare program, reference epidemiological data are needed. A sensitive diagnostic instrument is needed for examining very young children in a population with expected extensive caries situation. The instrument should cover the full spectrum of dental caries, including enamel carious lesions and those with extensive dental pathology. This requirement excludes the WHO criterion, which only considers presence or absence of a dentine cavity. Moreover, the International Caries Detection and Assessment System (ICDAS) is not complete, because it does not record extended dental pathology into the pulp and mucosal tissue ${ }^{8}$. The caries assessment tool that appears to meet these requirements is the recently developed and validated Caries Assessment Spectrum and Treatment (CAST) instrument. CAST uses the epidemiological concept of health and disease and considers treated surfaces with sealants and restorations as healthy. The CAST codes are hierarchically ordered from no carious lesion through a carious lesion in enamel and in dentine to pulp-involved and abscessed teeth, and teeth missing due to dental caries ${ }^{9}$. The present study is the first to present the results of a caries epidemiological survey that used the CAST instrument as recommended in the CAST manual ${ }^{10}$ and used its severity score ${ }^{11}$.

Information on the prevalence and severity of dental caries amongst youth in Lima is scarce, outdated and published in Spanish. To counter this paucity of information and as dental caries reference data are required to monitor carious lesion development across the younger sector of the population in the future, the present study was conducted with the aim of reporting the caries situation of three-year-old preschool children residing in three low SES districts.

\section{MATERIALS AND METHODS}

\section{Ethical approval}

Ethical approval for the study was obtained from the Institutional Review Board of the Dental School of San Martin de Porres University (Lima-Peru) (Resolution No. 252-2013-D-FO-USMP). This cross-sectional study is related to a randomized clinical trial (RCT) that is registered in the Netherlands Trial Centre with number NTR $4510^{12}$. Parents received a letter with general information about the epidemiological survey and an informed consent form. They were requested to sign the form and return it to the school authorities. Only children whose parents had signed and returned the form were included in the study. Every parent received a short report on their child's oral condition and suggestions for treatment, and was advised to contact the health center dentist. The research was conducted in full accordance with the World Medical Association Declaration of Helsinki.

\section{Study design}

The sampling units for the present survey were healthcare centers with well-functioning district mother-and-child health clinics, located in three districts from low socio-economical stratum (SES) 
areas in Lima, Peru. The selection was guided by economic indicators used by the Peruvian National Institute of Statistics and Informatics ${ }^{13}$. From a total 10 eligible districts, 3 were randomly selected $(\mathrm{AG}=$ district $1, \mathrm{PG}=\operatorname{district} 2$ and $\mathrm{CG}=\operatorname{district} 3)$. In each of the three selected districts, there was a healthcare center with a well-functioning motherand-child health clinic.

On the basis of being situated within $2 \mathrm{~km}$ radius from the healthcare center, a total 45 government preschools were randomly selected to participate, of which 17 agreed to take part in the present survey. Three-year-olds from these schools who had visited the mother-and-child vaccination clinics and growth and development program at the selected health canters from birth were invited to participate in the current survey. Invitation letters were sent to the parents.

\section{Caries assessment}

Caries assessment was conducted by two pediatric dentists who were experienced in performing epidemiological surveys among young children in a field situation. Prior to the examinations, the dentists were trained to use the CAST instrument and calibrated under the guidance of a senior epidemiologist (JEF). The training involved a theoretical explanation of the CAST codes, their descriptions and background information and a practical session in applying CAST to 20 extracted teeth, each mounted in an acrylic base. The examiners' scores were compared and differences discussed until consensus was reached. One week after the training, the examiners visited a school that was situated far away from the three study districts and which conformed to the same socio-economic profile as the survey schools. The examiners and a senior researcher (RV) examined 20 4-year-old children and compared and discussed the findings until they were all in agreement. The examiners examined eight children one week later to conduct the examiner agreement tests. The kappa-coefficient values for inter- and intra-rater reliability for the two examiners were 0.75 and 0.81 , and 0.74 and 0.75 , respectively. These results were considered sufficiently high to begin the epidemiological survey.

The oral examinations were performed at the preschool facilities. Prior to examination, patients' teeth were cleaned with a toothbrush, toothpaste and floss (when needed) by the first author. The child lay on a cushioned table with plastic cover and the examinations were performed using sterile instruments, gauze and a battery-powered headlamp (Energizer 3 LED headlamp, Energizer Holdings Inc. USA). All surfaces of all teeth were assessed according to the CAST instrument (Table 1). The $\mathrm{CPI}$ probe was used to remove any plaque that was left behind after tooth brushing. Each tooth was dried with gauze. As they made the oral examination, the examiner's commentary was recorded on a digital device and transcribed on an Excel sheet. The device measured examination time.

\section{Disposition of subjects}

A total 450 children were approached. Of these, the parents of 308 children signed the consent form and those children were consequently examined.

\section{Statistical analysis}

All children from the 17 preschools who fulfilled the inclusion criteria and were present on the examination day were examined. Data were analyzed by an experienced statistician using the statistical package SPSS version 24.0 (IBM. Armonk NY, USA).

CAST codes 0-2 and code 8 are excluded from the calculation of the prevalence of dental caries as they are not considered to reflect a diseased situation. The prevalence of dentine carious lesions (dental caries) is calculated using CAST codes 4-7. CAST codes 3-7 are used for calculating the prevalence of enamel and dentine carious lesions combined. Reporting the dental caries situation using the CAST instrument includes the maximum ( $\max$ ) CAST code per tooth (the highest code among the codes of all surfaces on an examined tooth); the max CAST code per subject (the highest code among the codes of all teeth examined in a subject); and the CAST severity score, which is obtained by first selecting the max CAST code per tooth and applying it to Formula F1, as shown below ${ }^{11}$ :

$$
\begin{aligned}
\mathrm{F} 1= & 0.25 * \mathrm{CAST} 3+1 * \mathrm{CAST} 4+2 * \mathrm{CAST} 5+ \\
& 4 * \mathrm{CAST} 6+5 * \mathrm{CAST} 7+6 * \mathrm{CAST} 8
\end{aligned}
$$

The 'number*' denotes the weight given to the accompanied CAST code. CAST codes 0,1 and 2 are not part of this formula since they indicate healthy condition. CAST scores 3-8 make up the formula and are assigned weights that increase with the 


\begin{tabular}{|c|c|c|c|}
\hline Characteristic & Disease status & CASTcode & Description \\
\hline Sound & Healthy & 0 & No visible evidence of a distinct carious lesion is present \\
\hline Sealant & Healthy & 1 & $\begin{array}{l}\text { Pits and/or fissures are at least partially covered with a sealant } \\
\text { material }\end{array}$ \\
\hline Restoration & Healthy & 2 & A cavity is restored with an (in)direct restorative material \\
\hline Enamel & (Pre)morbidity & 3 & $\begin{array}{l}\text { Distinct visual change in enamel only. A clear caries related disc- } \\
\text { olouration is visible, with or without localised enamel breakdown }\end{array}$ \\
\hline \multirow[t]{2}{*}{ Dentine } & Morbidity & 4 & $\begin{array}{l}\text { Internal caries-related discolouration in dentine. The discoloured } \\
\text { dentine is visible through enamel which may or may not exhibit a } \\
\text { visible localised breakdown of enamel }\end{array}$ \\
\hline & Morbidity & 5 & Distinct cavitation into dentine. The pulp chamber is intact \\
\hline Pulp & Severe Morbidity & 6 & $\begin{array}{l}\text { Involvement of pulp chamber. Distinct cavitation reaching the } \\
\text { pulp chamber or only root fragments are present }\end{array}$ \\
\hline Abscess/Fistula & Severe Morbidity & 7 & $\begin{array}{l}\text { A pus containing swelling or a pus releasing sinus tract related } \\
\text { to a tooth with pulpal involvement }\end{array}$ \\
\hline Lost & Mortality & 8 & The tooth has been removed because of dental caries \\
\hline Other & & 9 & Does not correspond to any of the other descriptions \\
\hline
\end{tabular}

increase in the CAST codes: an increase in severity. The maximum weight is assigned to CAST 8, which indicates tooth loss (mortality). Consequently, the higher the final CAST severity score, the worse the carious condition of the tooth or dentition ${ }^{11}$. A cumulative MaxCASTsubject is calculated using the highest CAST code for a person. Mean dmf/DMF scores can be calculated using CAST for comparison with studies done in the past ${ }^{14}$.

The CAST severity scores were compared among the three groups using ANOVA. Post hoc analyses were undertaken according to the method of Tamhane, which is suitable if variances between groups are different. Significance level was set at $p<0.05$.

\section{RESULTS}

The sample consisted of $55.8 \%$ girls and $44.2 \%$ boys. Children's mean age was 3.4 years (min: 3 years; max: 3 years, 7 months). Mean time to examine the children was 57 seconds (range 34-130 seconds).

\section{Prevalence of carious lesions}

For the whole sample, prevalence was $58.8 \%$ for dentine carious lesions (CAST codes 4-7) and 91.2\% for enamel and dentine carious lesions (CAST codes 3-7 combined). These values did not differ significantly across intervention groups (Table 2). CAST severity score for the sample was 7.0 with confidence limits of 6.0 to 7.9 . It was significantly higher for PG (9.8) than for AG (5.5) $(\mathrm{p}=0.003)$ and CG (5.9) $(\mathrm{p}=0.011)$. Mean dmft score was 2.6 with SD 3.2 .

\section{Distribution of CAST codes by teeth}

All but one child had 20 teeth. In the sample, sound teeth were seen most often $(66.0 \%)$, followed by teeth with enamel carious lesions $(20.8 \%)$ and teeth that had a restorable dentine carious lesion $(9.2 \%)$. The proportion of teeth with cavities that had reached the pulp and those that had an abscess/fistula was $2.0 \%$ and $0.5 \%$ respectively. The majority of enamel and dentine carious lesions were observed in molar teeth, followed by incisors. The prevalence of dentine carious lesions in incisors, cuspids, $1^{\text {st }}$ and $2^{\text {nd }}$ molars was $8.9 \%, 3.1 \%, 25.9 \%$ and $25.6 \%$, respectively.

\section{Distribution of CAST codes per child}

The frequency distribution of the maximum CAST code per child by sample is presented in Figure 1. Most children in the sample had a restorable dentine carious lesion as the highest code (35.4\%), followed by a tooth with an enamel carious lesion (32.5\%). An unexpectedly high percentage of children had cavities that had reached the pulp (15.6\%). This phenomenon was most prevalent in children from the PG group. Figure 2 shows the frequency distribution of enamel lesions and dentine lesions (cavitated) in the three districts included in the study. 
Table 2. Carious lesion prevalence (\%), CAST severity scores and mean dmft-scores by group and sample

\section{Caries prevalence}

(\%)

All carious lesions
CAST codes (3-7)

Dentine lesions

CAST codes (4-7)

CAST severity score

95\% Confidence Interval

Mean dmft-score (SD)

$\mathrm{AG}=$ District $1 ; \mathrm{PG}=$ District 2; $\mathrm{CG}=$ District 3

$P_{2}=0.003 ; P_{1}=0.011$

$\mathrm{SD}=$ Standard Deviation
Districts included

\begin{tabular}{|c|c|c|c|}
\hline AG & PG & CG & Sample \\
\hline $91.0 \%$ & $92.8 \%$ & $90.0 \%$ & $91.2 \%$ \\
\hline $51.4 \%$ & $64.9 \%$ & $61.0 \%$ & $58.8 \%$ \\
\hline $5.5^{\mathrm{a}}$ & $9.8^{\mathrm{b}}$ & $5.9^{\mathrm{c}}$ & 7.0 \\
\hline $4.1-6.8$ & $7.6-12.0$ & $4.6-7.3$ & $6.0-7.9$ \\
\hline $2.1(2.9)$ & $3.4(3.8)$ & $2.4(2.9)$ & $2.6(3.2)$ \\
\hline
\end{tabular}

The burden of dentine carious lesion was lowest in the AG group, but these children showed the highest prevalence of carious lesions in enamel.

\section{DISCUSSION}

The present survey is the first to have used the CAST instrument amongst three-year-olds, and presented the CAST severity score and reported epidemiological results differently from the usual way. Mean dmf-scores were calculated using CAST codes but, in essence, they are not needed ${ }^{14}$. They are included in the present report to enable comparison with previous studies conducted in Peru that used the dmf index. The CAST instrument was used in a study among two- to four-year-olds in Tanzania, but the results were presented as mean

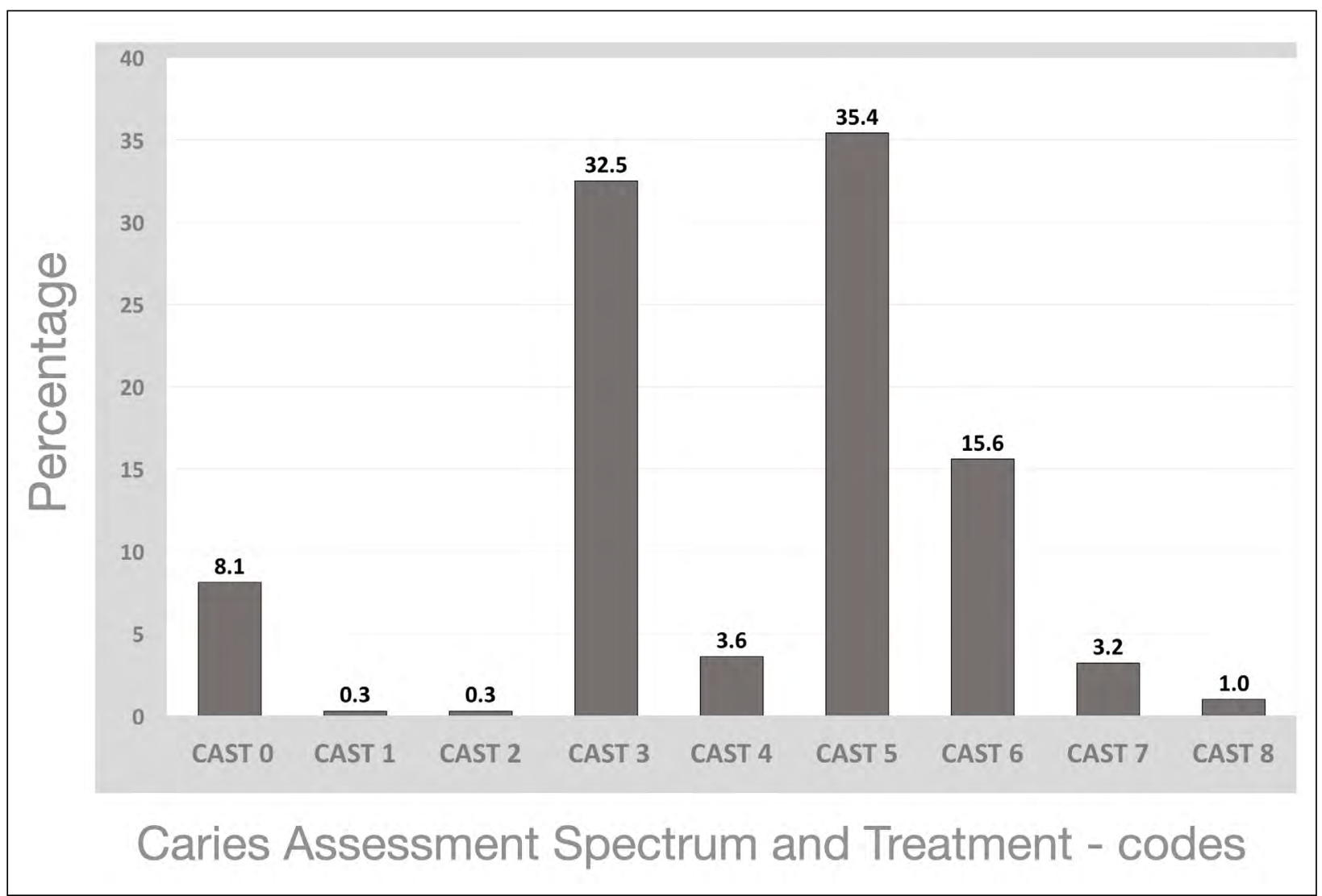

Fig. 1. Frequency distribution (\%) of maximum CAST code per child for the total sample of three-year-olds. 


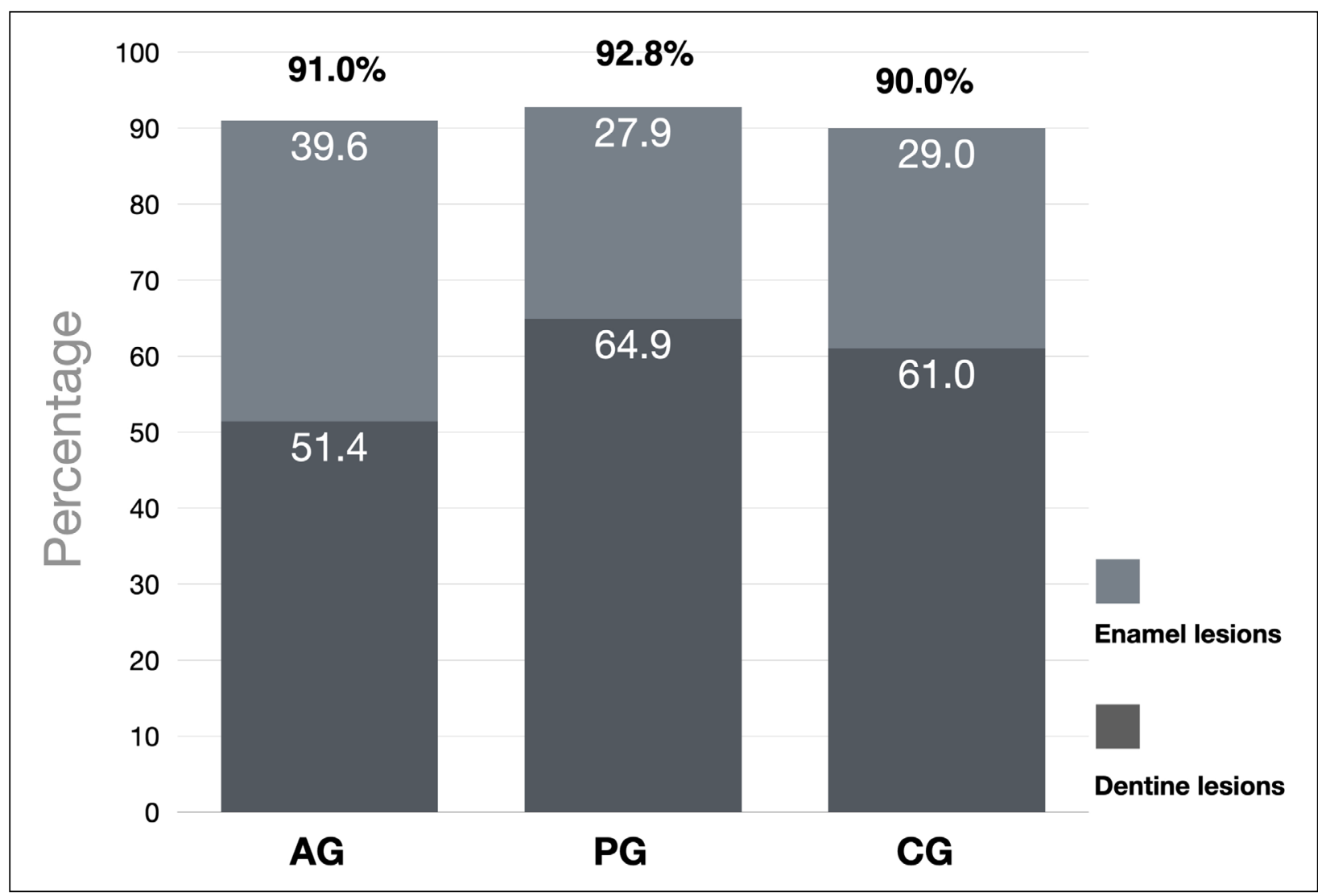

Fig. 2. Frequency distribution (\%) of enamel lesions (non-cavitated) and dentine lesions (cavitated) in the three districts included in the study. $A G=$ District 1; $P G=$ District 2; $C G=$ District 3 .

dmft-scores only ${ }^{15}$. The dmf-index has been used over many years and is considered outdated because it mixes active disease with treated disease. Such a combination is unable to show gains in health after intervention ${ }^{16}$. The CAST instrument considers treated teeth as no longer diseased, and therefore enables the expression of improvement in the caries situation in populations over time, by showing lower dentine carious lesion prevalence and lower caries severity score.

Prevalence of dentine carious lesions in the present study was $58.8 \%$. If enamel carious lesions are included in the disease calculation, prevalence increases to $91.2 \%$. It can only be concluded that dental caries is highly prevalent among young children with low SES. Epidemiological studies at this early age are important because they provide data for decision-makers, who should implement preventive strategies from birth rather than waiting and having to repair the consequences of the disease. To prevent dentine cavities, sugar consumption should be reduced and oral hygiene improved, which may require unconventional actions. These strategies should be carried out by dental health care providers at the mother-and-child health clinics in healthcare centers.

A similar high prevalence of dentine carious lesions $(62.3 \%)$ was observed in a different low-SES group of Peruvian three-year-olds ${ }^{17}$. In Cambodia ${ }^{18}$ and Vietnam, ${ }^{19}$ the prevalence of dentine carious lesions among three-year-olds was also very high, at $65.6 \%$ and $74 \%$ respectively. However, the opposite has also been reported. In Nigeria, the prevalence among this age group was $1 \%{ }^{20}$ and in Tanzania, among two- to four-year-olds, the prevalence of dentine carious lesions was $5.3 \%{ }^{15}$. The results of the latter two studies show that dentine carious lesion development can be managed.

Apart from the high prevalence of dentine carious lesions, the prevalence of enamel carious lesions was also high (42.5\%). These enamel and dentine carious lesions have developed over the first 30 months of the life of these infants. During that relatively short period, $15.5 \%$ of these infants had pulp-involved 
carious teeth and $3.2 \%$ of infants had an abscess. Posterior teeth were more affected by dentine carious lesions than anterior teeth. Considering that molars start emerging when the infant is 18to 30 -months old, it is clear that parents/members of these communities need to be guided in keeping erupted teeth healthy as early in the life of the infant as possible. Early childhood caries could extend its consequences to permanent dentition, generating a life-long burden of disease to the individual ${ }^{21}$.

Since the first publication in $2011^{22}$, the CAST instrument has been studied, applied and discussed in an ever-growing number of publications from different countries. It has the advantage over ICDAS that it also includes carious lesions with pulp involvement and abscessed teeth. CAST does not differentiate cavitated from non-cavitated enamel lesions, which might be a subject for discussion. However, as CAST is meant for use in epidemiological surveys, in contrast to ICDAS, which is also meant to be used in private practice, having one code for determining the presence of an enamel lesion is considered sufficient and realistic. Additionally, the three ICDAS codes for scoring enamel carious lesion are combined in reporting the results, which calls to question the need for three $\operatorname{codes}^{16}$. CAST makes a distinction between dentine carious lesions that can be treated restoratively and that have reached the pulp. Presenting the results as cumulative CAST codes per child, as shown in Figure 2, makes it possible to identify the level of disease in a community very easily. The longer the

\section{ACKNOWLEDGMENTS}

We thank Diana Zelada and Julia Diaz for their invaluable work; all the preschool directors and teachers who supported the research team in examining the children, and especially all the participants. We also thank Mrs. Susan van Tonder for editing the English language.

\section{FUNDING}

This research was funded by the World Dental Federation (FDI) through its World Dental Development Fund and supported by the Radboud University Medical Centre, Nijmegen, The Netherlands, and the Department of Pediatric Dentistry of the San Martin de Porres University, Dental School, Lima, Peru. line remains low, the more diseased the population is. These advantages have been documented in studies where the CAST instrument has been applied $^{23-25}$.

Compared to the WHO caries assessment criterion, CAST took an equally short time to complete the assessment of 7- to 11-year-olds and the mean dmf/ DMF scores derived from the CAST data did not differ significantly from those obtained by using the WHO criterion ${ }^{14}$. The advantage of CAST over the WHO criterion is related to the more detailed collection of data of the caries process rather than recording the presence of a dentine cavity, a restoration and an extracted tooth.

The present survey has limitations. The results are not representative of the dental caries situation of three-year-olds in Lima. Its internal and external validity is therefore low. The drop-out percentage of $31.6 \%$ can be considered substantial but is apparently not uncommon (parents who did not sign the informed consent) in children from low-SES populations ${ }^{4}$ and the final sample met the required sample size. Notwithstanding these limitations, the survey has provided results that should alarm the authorities and the dental profession in Lima and that necessitate a tailor-made solution.

\section{CONCLUSION}

The burden of dental caries in this group of threeyear-olds is alarmingly high. This report can facilitate future decision-making regarding health policies for populations.

\section{CORRESPONDENCE}

Dr. Eraldo Pesaressi

Av. General Córdova 281,

Miraflores.

Lima, Perú.

epesaressit@usmp.pe 


\section{REFERENCES}

1. Marcenes W, Kassebaum NJ, Bernabé E, Flaxman A, Naghavi M, Lopez A, Murray CJ. Global burden of oral conditions in 1990-2010: A systematic analysis. J Dent Res 2013;92:592-597.

2. Feitosa S, Colares V, Pinkham J. The psychosocial effects of severe caries in 4-year-old children in Recife, Pernambuco, Brazil. Cad Saude Publica 2005;21:1550-1556.

3. Sheiham A. Dental caries affects body weight, growth and quality of life in pre-school children. Brit Dent J 2006;201:625-626.

4. Leal SC, Bronkhorst EM, Fan M, Frencken JE. Untreated cavitated dentine lesions: Impact on children's quality of life. Caries Res 2012;46:102-106.

5. Piovesan C, Tomazoni F, Del Fabro J, Buzzati BC, Mendes FM, Antunes JL, Ardenghi TM. Inequality in dental caries distribution at non-cavitated and cavitated thresholds in preschool children. J Public Health Dent 2014;74:120-126.

6. Pesaressi E, Villena RS, van der Sanden WJ, Frencken JE. Barriers to adopting and implementing an oral health programme for managing early childhood caries through primary health care providers in Lima, Peru. BMC Oral Health 2014;14:17.

7. De la Cruz GG, Rozier RG, Slade G. Dental screening and referral of young children by pediatric primary care providers. Pediatrics 2004;114:e642-652.

8. Pitts N. "ICDAS" - an international system for caries detection and assessment being developed to facilitate caries epidemiology, research and appropriate clinical management. Community Dent Health 2004;21:193-198.

9. Frencken JE, de Souza AL, van der Sanden WJ, Bronkhorst EM, Leal SC. The Caries Assessment and Treatment (CAST) instrument. Community Dent Oral Epidemiol 2013;41:e71-77.

10. Frencken JE, de Souza Hilgert AL, Bronkhorst EM, Leal SC. CAST: Caries Assessment Spectrum and Treatment. Manual. Nijmegen: Ipskamp Drukkers; 2015. p. 47.

11. Ribeiro APD, Maciel IP, de Souza Hilgert AL. Caries assessment spectrum treatment: The severity score. Int Dent J 2018;68:84-90.

12. Pesaressi E, Villena RS, van der Sanden WJM, Frencken JE. Impact of health centre nurses on the reduction of early childhood caries in Lima, Peru. Brit J Med Med Res 2015;5:1169-1176.

13. Peruvian National Institute of Statistics and Informatics (INEI). [cited 2018 April] Available from: http://iinei.inei. gob.pe/microdatos/

14. de Souza A, Leal S, Bronkhorst E, Frencken JE. Assessing caries status according to the CAST instrument and WHO criterion in epidemiological studies. BMC Oral Health 2014;14:119.

15. Mwakayoka H, Masalu JR, Namakuka Kikwilu E. Dental caries and associated factors in children aged 2-4 years old in Mbeya City, Tanzania. J Dent (Shiraz) 2017;18:104111.16.

16. Frencken JE, Giacaman RA, Leal SC. An Assessment of Three Contemporary Dental Caries Epidemiological Instruments: A Critical Review. Br Dent J 2020 228:25-31

17. Villena-Sarmiento R, Pachas-Barrionuevo F, Sanchez-Huaman Y, Carrasco-Loyola M. Prevalence of early childhood caries in children under 6 years old, living in marginal communities in the north of Lima. Rev Estomatol Hered 2011;21:79-86. http://www.upch.edu.pe/vrinve/dugic/revistas/index.php/REH/article/view/237/204

18. Turton B, Durward C, Manton D, Bach K, Yos C. Socio-behavioural risk factors for early childhood caries (ECC) in Cambodian preschool children: A pilot study. Eur Arch Paediatr Dent 2016;17:97-105.

19. Khanh LN, Ivey SL, Sokal-Gutierrez K, Barkan H et al. Early childhood caries, mouth pain, and nutritional threats in Vietnam. Am J Public Health 2015;105:2510-2517.

20. Folayan MO, Kolawole KA, Oziegbe EO, Oyedele T, Oshomoji OV, Chukwumah NM, Onyejaka N. Prevalence, and early childhood caries risk indicators in preschool children in suburban Nigeria. BMC Oral Health 2015;15:72.

21. Alm A, Wendt LK, Koch G, Birkhed D. Prevalence of approximal caries in posterior teeth in 15-year-old Swedish teenagers in relation to their caries experience at 3 years of age. Caries Res 2007;41:392-398.

22. Frencken JE, de Amorim RG, Faber J, Leal SC. The Caries Assessment Spectrum and Treatment (CAST) index: Rational and development. Int Dent J 2011;61:117-123.

23. Baginska J, Rodakowska E, Milewski R, Kierklo A. Dental caries in primary and permanent molars in 7-8-year-old schoolchildren evaluated with Caries Assessment Spectrum and Treatment (CAST) index. BMC Oral Health 2014;14:74.

24. Shyam R, Manjunath BC, Kumar A, Narang R, Goyal A, Piplani A. Assessment of dental caries spectrum among 11 to 14-year-old school going children in India. J Clin Diagn Res 2017;11:ZC78-ZC81.

25. El Batawi H, Fakhruddin KS. Patterns of dental caries among school children assessed using Caries Assessment Spectrum and Treatment tool. Eur J Dent 2017;11:168173. 